\title{
Impact of integration of import tariff policy and strategic programs to increase milk production on the availability of fresh milk in Indonesia
}

\author{
Ratna Ayu Saptati* and Priyono \\ Indonesian Center for Animal Research and Development, Jl. Raya Pajajaran Kav E-59, Bogor, \\ Indonesia
}

\begin{abstract}
The gap of growth in milk consumption that is not in line with the growth of milk production has resulted in the need for imports. Indonesian government intervenes in import regulation through the implementation of import tariff policy and strategic programs to increase domestic milk production. The study aimed to analyze the impact of the integration of both interventions on accelerating the growth of fresh milk production in Indonesia. The research method is a descriptive method that uses BPS, Pusdatin, and other second-hand data published in previous studies. A comparative study of producer and consumer surplus and a modeling analysis of strategic policies to increase the production of domestic fresh milk was used. The results of the analysis revealed that the impose of 5\% import tariff on milk has an impact on increasing producer surplus, decreasing consumer surplus and public welfare, also increasing the government's revenue. The results of model simulation showed that the recommended combination scenario of increasing milk productivity, calf rearing, and broodstock import is the best scenario. Hence, the import tariff policy recommendations combined with the strategic programs can accelerate the increase in the supply of fresh milk in Indonesia.
\end{abstract}

\section{Introduction}

The demand for milk in Indonesia is increasing along with the increase in population growth and public awareness of the animal protein consumed. The main product of dairy cows has a high economic value, both for milk producers (dairy farmers) and the milk processing industry (IPS). Milk consumption in Indonesia now reaches 16.23 liters/capita/year [1]. Although the level of milk consumption is still lower than some other ASEAN countries, such as Malaysia (36.2 liters/capita/years), Myanmar (26.7 liters/capita/year), Thailand (22.2 liters/capita/year), and the Philippines (17.8 liters/capita/year), the prospect of developing the dairy industry in Indonesia is still open widely. This is due to the increase in population (1.25\% per year from 2010 to 2020) and per capita milk consumption ( $0.49 \%$ per year from 2000 to 2020) [2].

Consumption of powdered milk (dried milk) dominates milk consumption in Indonesia, while consumption of both fresh and processed liquid milk (pasteurized milk and ultra heat

\footnotetext{
${ }^{*}$ Corresponding author: ratnaayusaptati@yahoo.com
} 
temperature/UHT milk) is still very low. The IPS is more dominant in producing powdered milk than liquid milk, where most of the raw materials for powdered milk come from imports in the form of skim milk powder, anhydrous milk fat, and buttermilk powder. The main importing countries are Australia, New Zealand, the United States, and the European Union. Efforts to increase public awareness to consume more fresh milk need to be done by the government, as well as efforts to encourage the IPS to produce more fresh processed milk rather than powdered milk. According to Susenas Data from 1993 to 1998, consumption of processed fresh milk increased by an average of 0.20 liters/capita/year, and even in 2018 , it increased by $106.71 \%$ [1]. However, fresh milk produced in Indonesia is still unable to keep up with the national demand for milk.

The total demand for milk in 2020 was 4,385,730 tons, with domestic production of fresh milk only $947,685.36$ tons $(22 \%)$. Thus, there is a gap between the demand for milk, which is far above the national supply of national fresh milk. There is no other choice, due to limited local milk production capacities, Indonesia still relies heavily on milk imports. In order to meet this demand, there is still a gap of 3,392,760 tons, which is realized through import [2]. In 24 years, from 1996 to 2020, imports were far higher than exports, resulting a trade deficit [1]. Data from Bureau of Statistics (BPS) show that milk import in 2020 are 541,6 million U.S. dollars, which is much higher than the total milk exports. Most of the imported milk is in the form of semi-processed raw materials, such as skim milk powder, anhydrous milk fat, and buttermilk; and final-processed raw materials, such as powdered milk, cheese, and butter.

Seeing the development of the dairy industry in Indonesia so far, the question arises whether the dairy industry market is already appropriate or will it need directing to the free market. So far, the government has chosen to intervene in policies that are able to protect domestic fresh milk producers (dairy farmers) to survive, while paying attention to the business activities of IPS. The intervention taken by the government is to issue a policy that regulates import tariffs for milk.

According to the Minister of Finance Regulation (Permenkeu) Number 6/2017 in the Stipulation of the Goods Classification System and the Imposition of Import Duty Tariff on Imported Goods, Indonesia imposes an import tariff for imported milk averaging 5\% for dairy products and $5-10 \%$ for fermented dairy products. What's more, the government applied a value-added tax of $10 \%$ for imports. The imported milk is classified into unconcentrated and concentrated milk and cream (Table 1.).

Table 1. Milk import tariff based on Minister of Finence Regulation (Permenkeu) Number 6/2017

\begin{tabular}{|l|l|c|c|}
\hline \multicolumn{1}{|c|}{ HS Code } & \multicolumn{1}{|c|}{ Description } & $\begin{array}{c}\text { Impor tariff } \\
(\%)\end{array}$ & $\begin{array}{c}\text { State Income Tax } \\
(\%)\end{array}$ \\
\hline 0401.10 .00 .00 & Fat content $<1 \%$ & 5 & 10 \\
\hline 0401.20 .00 .00 & Fat content $1-6 \%$ & 5 & 10 \\
\hline 0401.30 .00 .00 & Fat content $>6 \%$ & 5 & 10 \\
\hline 0402.10 .30 .00 & Fat content $<1.5 \%$ (powder without sugar) & 5 & 10 \\
\hline 0402.10 .90 .00 & $\begin{array}{l}\text { Fat content }>1.5 \% \% \text { (powder without } \\
\text { sugar) }\end{array}$ & 5 & 10 \\
\hline 0402.21 .20 .00 & Fat content $<1.5 \%$ (powder + sugar) & 5 & 10 \\
\hline 0402.21 .90 .00 & Fat content $>1.5 \%$ (powder + sugar) & 5 & 10 \\
\hline 040229 & Others & 5 & 10 \\
\hline 040310 & Yoghurt & 10 & 10 \\
\hline
\end{tabular}

Source: [3] 
According to the previous regulations, that is, the Minister of Finance Order No. $16 / \mathrm{KMK} / 01 / 1998$, the import tariffs on milk raw materials and final products initially ranged from $5 \%$ to $30 \%$, and now they are changed to $5 \%$ between the two due to no distinction. At first, the import tariff for milk raw materials, consisting of skim milk powder, anhydrous milk fat, buttermilk, and lactose, set it to $5 \%$. For processed milk products consisting of milk powder, cheese, and butter, set it to $30 \%$.

In addition to the import tariff policy, the government through the Coordinating Ministry for the Economy has also issued the Indonesian Dairy Blueprint 2013 - 2025 [4]. In the blueprint, one of the targets to do is regulations that can encourage an increase in domestic fresh milk (SSDN) absorption by the processing industry, and an increase in consuming processed fresh milk through programs such as the school milk program [5]. Then, after revoking Presidential Decree No. 2 in 1985 without relevant regulations, the Minister of Agriculture issued Regulation No. 33 of 2018 on the supply and circulation of milk. In this regulation, there are strategic policies to accelerate the increase in the production of fresh milk in Indonesia. Fresh milk producers, mainly small-scale dairy farmers, need to be protected and increase their productivity.

Is it appropriate to apply import tariff policies and strategic policies to increase milk production? Is the import tariff policy for milk implemented by the government really able to protect farmers? Which party benefits and which party does not. What's more, what recommended policies to accelerate the increase in fresh milk in Indonesia?

The purpose of this paper is to (a) analyze the impact of implementing import tariff policies of milk on dairy farmers in Indonesia, and (b) analyze the impact of implementing strategic policies to increase milk production on fresh milk availability in Indonesia through model simulation.

\section{Research methodology}

The data sources used in this article were secondary data, including publications from BPS (Indonesian Statistics) and Agricultural Data and Information Center/PUSDATIN of the Ministry of Agriculture (Livestock Industry Outlook), other related research results, and policies and regulations implemented to increase milk production in Indonesia. The use of secondary data was mainly as a source of data/parameters used in the construction of simulation models. The analytical approaches carried out in this paper were: (a) graphical and quantitative approaches, referring to the theory of producer surplus and consumer surplus to get the amount of social welfare to analyze the impact of milk import tariffs on dairy farmers (producers); and (b) Model simulations to analyze the impact of implementing strategic policies to increase milk production on fresh milk availability in Indonesia.

Based on research results, textbooks, and government reports, the model was developed to accelerate the country's fresh milk supply. Some scenarios carried out for model simulation consisted of: (a) Scenario of increasing milk productivity; (b) Scenario of calf rearing program; (c) Combination scenarios of increasing milk productivity and calf rearing program; and (d) Combination scenarios of increasing milk productivity, calf rearing program, and imports of broodstock. Simulations were carried out using Microsoft Excel 2010 and Powersim Studio 10. 


\section{Results and discussion}

\subsection{Impact of the implementation of import tariff policy on dairy farmers (fresh milk producers)}

In general, the Government's intervention in regulating milk imports in Indonesia from the New Order era until now is the milk import ratio (BUSEP) and the milk import tariff policies. The policy framework adopted by the Indonesian government can be analyzed using the Tinbergen Framework Policy Analysis method [6]. The levied import tariff (import duties) is one of the policy interventions aimed at protecting farmers, by creating conditions to produce agricultural products that are beneficial to farmers [7].

This policy level is at the top of the hierarchy with a cross-sectoral policy scope, namely the agricultural, trade, and industrial sectors. Commercial participants in the dairy industry must accept the nature of this policy. The focus is on the goal of economic equity, namely the fair distribution of milk supply in Indonesia. In particular, the purpose of this policy is to protect dairy farmers and keep milk prices stable. The policy intervention on milk import ratio and import tariff aims to protect dairy farmers, IPS, and the dairy industry sustainability in Indonesia. The import tariff policy levied on imported milk raw materials and processed milk products is designed to protect farmers and IPS.

According to the research of Nurhiasati et al., the higher the import tariff, the higher the economic inefficiency, which indicates that the level of total social welfare is declining [8]. The comparative static analysis of the concepts of producer surplus and consumer surplus can be used to analyze public welfare (social welfare). Through policy interventions implemented in the dairy industry in Indonesia, the government can study the impact of changes in consumer surplus and producer surplus (decrease or increase), as well as social welfare.

The results of the comparative analysis of producer surplus and consumer surplus with a graphical approach show that there is a change in public welfare with the existence of a milk import tariff policy. Generally speaking, the role of tariffs is to provide economic protection for domestic production because it makes imported products more expensive on the domestic market. Figure 1 illustrates the implementation of the policy intervention on milk import tariffs.

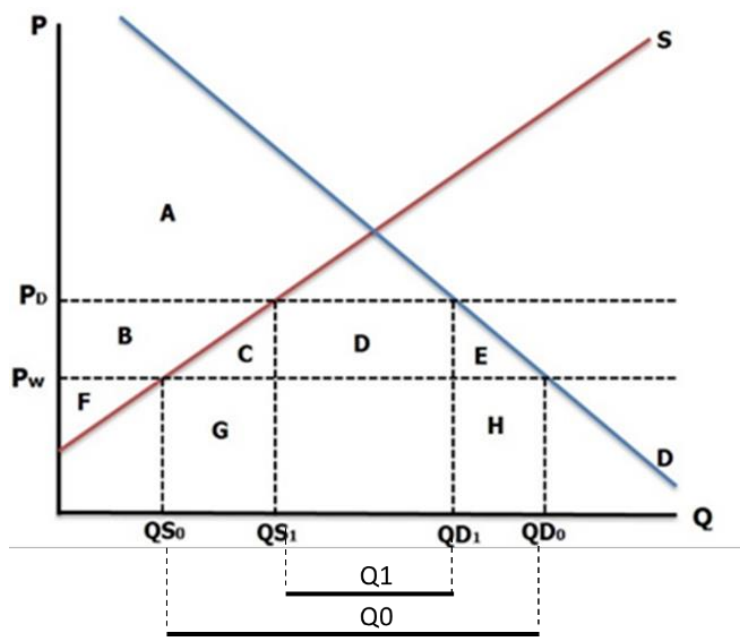

Fig. 1. The impact of imposition of milk import tariff 
Figure 1 illustrates the effects of import tariffs on milk. Consumer surplus without any policy intervention (free milk imports) is the area $(\mathrm{A}+\mathrm{B}+\mathrm{C}+\mathrm{D}+\mathrm{E})$ below the demand line (D) and above the price $\left(\mathrm{P}_{\mathrm{W}}\right)$. The area above the supply line $(\mathrm{S})$ and below the price $(\mathrm{Pw})$ is the producer's surplus or area $\mathrm{F}$.

The imposition of import duties on milk causes the domestic price to change (up) from $\mathrm{P}_{\mathrm{W}}$ to $\mathrm{P}_{\mathrm{D}}$. Consequently, domestic production will increase, domestic consumption will decrease and the level of imports will reduce from $Q_{0}$ to $Q_{1}$. This condition has an impact on changes in consumer surplus and producer surplus. The consumer surplus becomes the area below the demand line $(\mathrm{D})$ and above the new price $\left(\mathrm{P}_{\mathrm{D}}\right)$, so that the remaining consumer surplus is area $\mathrm{A}$. The producer gets the extra surplus of area $\mathrm{B}$, so the producer surplus becomes the area of $\mathrm{F}+\mathrm{B}$. Thus, the policy of an import tariff on milk has an impact on the distribution of income between market participants, namely a reduction in consumer surplus, an increase in producer surplus, and social losses in the form of production inefficiency and economic inefficiency. The implementation of import tariffs has a positive impact on production and a negative impact on consumption [9].

Table 2 shows the changes in social welfare with the implementation of the import tariffs on milk in Indonesia.

Table 2. Change in social welfare with the implementation of import tariff policies on milk

\begin{tabular}{|l|c|c|c|}
\hline \multicolumn{1}{|c|}{ Description } & $\begin{array}{c}\text { Free import (without } \\
\text { policy intervention) }\end{array}$ & $\begin{array}{c}\text { Policy intervention } \\
\text { on import tariff }\end{array}$ & $\begin{array}{c}\text { Change in welfare } \\
\text { (Social Welfare })\end{array}$ \\
\hline $\begin{array}{l}\text { Consumer surplus } \\
\text { (CS) }\end{array}$ & $\mathrm{A}+\mathrm{B}+\mathrm{C}+\mathrm{D}+\mathrm{E}$ & $\mathrm{A}$ & $-(\mathrm{B}+\mathrm{C}+\mathrm{D}+\mathrm{E})$ \\
\hline $\begin{array}{l}\text { Producer surplus } \\
\text { (PS) }\end{array}$ & $\mathrm{F}$ & $\mathrm{B}+\mathrm{F}$ & $\mathrm{B}$ \\
\hline Import tariff (T) & 0 & $\mathrm{D}$ (tariff) & $\mathrm{D}=5 \%$ \\
\hline $\begin{array}{l}\text { Import Tariff } \\
\begin{array}{l}\text { Welfare } \\
\text { (CS+PS+T) }\end{array}\end{array}$ & $\mathrm{A}+\mathrm{B}+\mathrm{C}+\mathrm{D}+\mathrm{E}+\mathrm{F}$ & $\mathrm{A}+\mathrm{B}+\mathrm{D}+\mathrm{F}$ & $-(\mathrm{C}+\mathrm{E})^{*}$ \\
\hline
\end{tabular}

Note: * = Deadweight Lost (DWL)

Table 2 shows that the import tariff imposed on milk resulted in the loss of consumer surplus by an area of $\mathrm{B}+\mathrm{C}+\mathrm{D}+\mathrm{E}$. The area $\mathrm{D}$ does not become deadweight loss (DWL), but becomes the revenue for the government. Therefore, in the import tariff levied on milk, for the public welfare, the missing area (DWL) is the area of $\mathrm{C}+\mathrm{E}$. This phenomenon agrees with the research of Fariyantiwhich analyzed the impact of the import tariff policy on white sugar, that the import tariff of IDR $700 / \mathrm{kg}$ will increase the welfare of producers and government revenues, but on the other hand, this causes the welfare of consumers and society as a whole to decrease [10].

Using a quantitative approach, it showed that the consumer surplus declined by as much as the area of $\mathrm{B}+\mathrm{C}+\mathrm{D}+\mathrm{E}$ due to the import tariff implemented on milk. The producer surplus increased by area B which is the consumer surplus lost as a result of the implementation of the policy. Through the stock and flow chart, it is possible to compare $0 \%$ tariff and 5\% tariff applications, which is simulated with Powersim Studio 10. Figure 2 shows a schematic diagram of the implementation of the milk import tariff policy. 


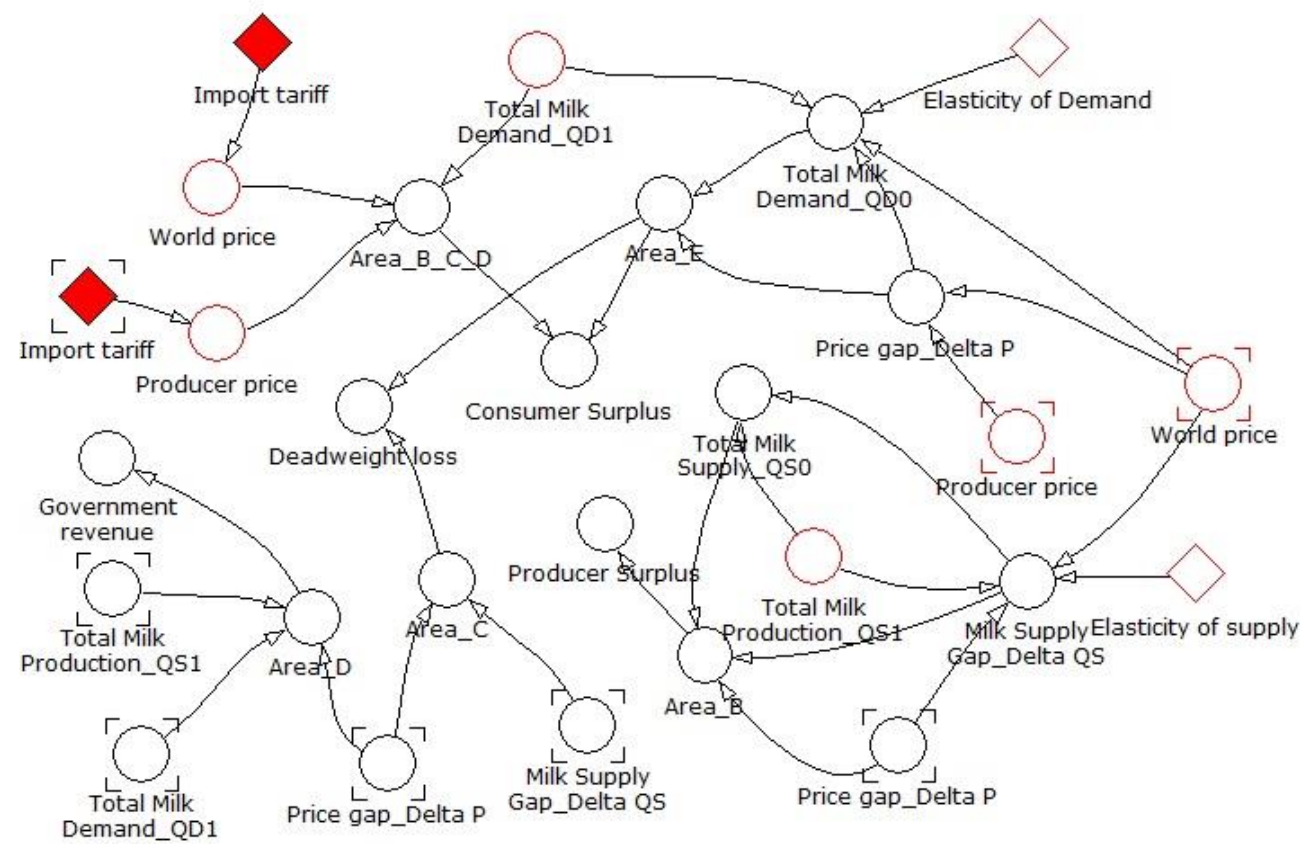

Fig. 2. Diagram of the policy implementation of impor tariff on milk

According to Figure 2, the lost consumer surplus (area $\mathrm{B}+\mathrm{C}+\mathrm{D}+\mathrm{E}$ ) is because area $\mathrm{B}$ is transferred to the extra surplus received by the producer, and for area $\mathrm{D}$, it is transferred to the surplus received by the government. This kind of government revenue will increase with the increase in tariffs imposed, and will decrease after reaching equilibrium, which is opposite to the increase in tariffs. Thus, the area of $\mathrm{C}+\mathrm{E}$ is social welfare that cannot be enjoyed by both producers and consumers (deadweight loss/DWL). The research results of Sinuraya et al. show that the application of 20-30\% import tariffs has an impact on changes in imports, domestic prices, consumer welfare, producer welfare, and government revenue [11]. The research of Putri et al. on corn commodities, also pointed out that Indonesia's removal of corn import tariffs from AFTA and non-AFTA countries reduced the producer's surplus [12].

Fitriana et al.'s research on shallot commodities and Nurhiasati et al. on soybean commodities also show the same phenomenon, that the implementation of an import tariff has an impact on increasing producer welfare and government revenues, but decreasing consumer welfare $[13-8]$. The result of the study also said that the application of a $9 \%$ import tariff was able to protect shallot farmers from a decline in world prices. In addition, according to Siswanto et al. that a single policy is not able to improve the welfare of producers and consumers, such as a combination of policy packages to increase production main prices (HPP), increase agricultural credit, and fertilizer subsidies aimed at improving the welfare of producers and consumers [14].

\subsection{The impact of strategic programs to increase milk production on speeding up the supply of fresh milk in Indonesia}

In addition to the import tariff policy in accordance with the Minister of Finance Regulation No. 6 of 2017 [15], it is necessary to make policy recommendations with a quantitative 
model based on regulations that refer to the Minister of Agriculture No. 33 of 2018 [16]. The basis for the formulation of the simulation model refers to the first paragraph of Article 2 of Chapter II. i.e. Provision of milk to meet domestic through (a) domestic production; and (b) importation from abroad; and (2) Paragraphs 2 and 3 of Article 3 of Chapter II, i.e., in the supply of milk, it is necessary to increase production through increasing productivity, the number of cows and milk quality.

The development of the national fresh milk supply acceleration model for upstream subsystems, dairy companies, artificial insemination suppliers, cement suppliers, concentrated feed plants, and cowshed equipment suppliers have all played a key role. Meanwhile, smallholder dairy farmers who are mainly members of cooperatives, a few commercial farms and independent farmers dominate the farm subsystem. Independent farmers usually also sell fresh milk to cooperatives and processed milk (pasteurized milk) to consumers, although the quantity is small

In the downstream subsystem, there are two actors who play a very important and decisive role, namely cooperatives and the Dairy Processing Industry (IPS). The cooperative collects milk from milk producers (dairy farmers) and sells it back to IPS. The key to the risk factor in the supply chain of the dairy farming industry lies in the handling of milk, because dairy products are easily damaged [17]. The delay in collecting milk from farmers to cooperatives also affects the number of bacteria and milk quality [18]. There needs to be enough milk to meet the needs of consumers, and IPS responded to this.

Domestic milk production is determined mainly by the number of lactating dairy cows. Lactating cows are obtained by raising cows or purchased from a breeding company in the upstream subsystem. In calf rearing, it needs time of around 2 years until a female calf becoming a mature heifer. For male calves, the farmers raise them until weaned and then sold. This condition is in accordance with Lie et al. which states that farmers, generally, will sell weaned male calves at the age of about 5-7 months [19]. In this model, the calf rearing program by farmers and importation of mature heifers are the interventions in order to enhance the number of productive cows.

Milk production from farmers then becomes an inventory of national fresh milk availability, either through dairy cooperatives or directly carried out by commercial farms. The national fresh milk supply cannot meet the demand for IPS, so they have to import milk and dairy products to meet the demand. IPS will process milk and other dairy products according to the needs of consumers. In this downstream subsystem, there is a role from wholesalers, small traders, and retailers who act as intermediaries between The IPS and consumers. Population, household consumption, participation in milk consumption, and income elasticity influence the amount of consumer demand for milk.

Based on the developed model, four policy scenarios were prepared, namely: (a) policy scenario of increasing milk productivity; (b) policy scenario of calf rearing program; (c) combination scenarios of policy to increase milk productivity and calf rearing program; and (d) combination scenarios of policy to increase milk production, calf rearing program, and imports of broodstocks.

Figure 3 shows the simulation results of the above identified policy scenarios. In Figure 3 , the scenario of increasing milk productivity through the intervention of increasing milk productivity by 15 liters/cow/day, (Scenario 1) shows that the percentage of fresh milk production in 2025 will reach $26.50 \%$. Although the production of fresh milk can be increased through the intervention of Scenario 1, the increase is still lower than the increase in milk consumption demand (blue curve). Farmers can achieve a huge increase in milk productivity with a continuous supply of feed both in quantity and quality; also, good quality broodstocks. Generally speaking, farmers face the constraints of continuous supply of feed, imperfect infrastructure and insufficient sanitation services. 


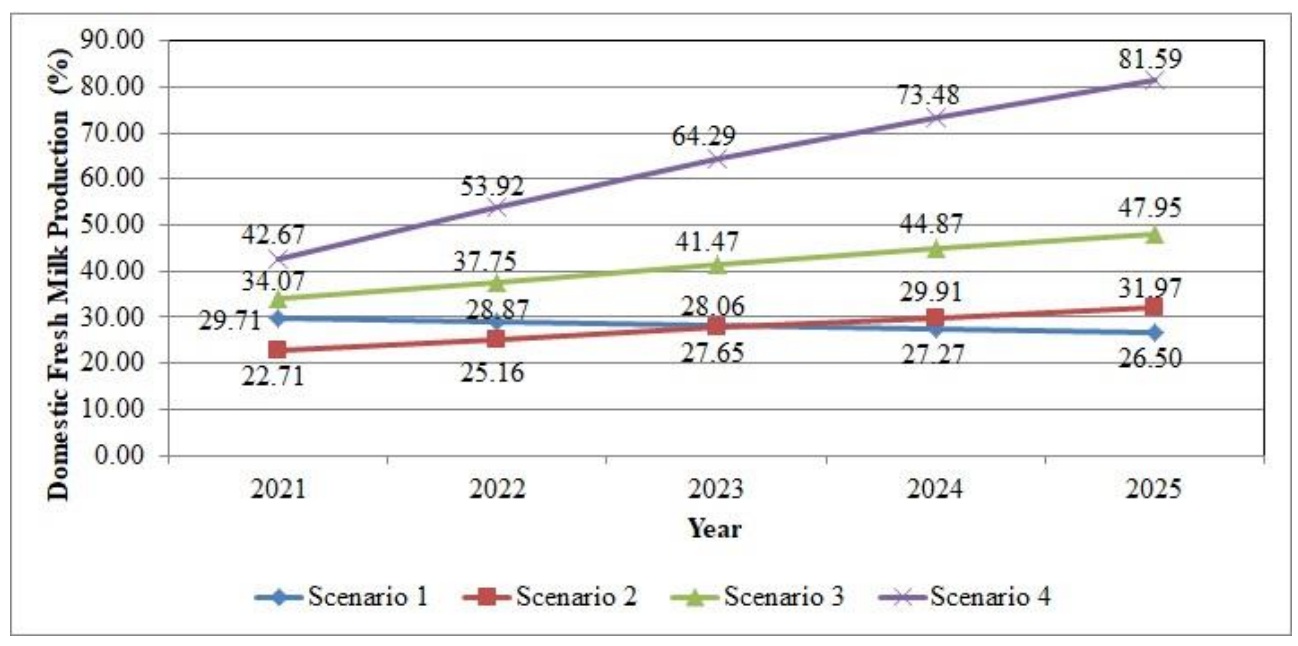

Fig. 3. Scenario simulation on policy strategics for fresh milk avalaibilty in Indonesia

Notes:

Scenario 1: Policy scenario of increasing milk productivity (15 liters/cow/day)

Scenario 2: Policy scenario of calf rearing program

Scenario 3: Combination scenarios of policy to increase milk productivity and calf rearing program Scenario 4: Combination scenarios of policy to increase milk production, calf rearing program, and imports of broodstocks

Based on scenario simulation 2, the calf rearing program, if successfully implemented in this field, will significantly increase the number of expected dairy cows. The calf rearing program can get more than 50 thousand additional brooders in a year. If the raised broodstock produces calves and then is continuously included in the calf rearing plan, the plan will have a multiplier effect. Under ideal conditions, additional broodstocks from the calf rearing program in 2021 will be around 57,101 heads, and in 2025, the number will increase to 72,762 heads. Production of fresh milk in 2025 will be $31.97 \%$ of total milk demand, using this scenario without a milk productivity program. This scenario is better than Scenario 1 (increase milk productivity by 15 liters/cow/day) with a percentage of SSDN production of only about $26.50 \%$ in 2025 . this scenario needs policy interventions so that actors in the on-farm subsystem raise female calves until they become heifers. The development of sustainable calf rearing with various mutually reinforcing policies can be a strategy for utilizing comparative advantage in the provision of prospective dairy cows [20].

Scenario 3, a combined scenario of increasing milk productivity and calf feeding plan, can reduce the country's milk shortage. The combination of increasing milk productivity by 15 liters/cow/day with the calf rearing program shows a milk deficit of $52.05 \%$ in 2025 , which reflects that domestic fresh milk production is approaching $50 \%$ (47.95 percent to be exact). This milk production can be an achievement because so far, domestic fresh milk production is still less than $30 \%$. The calf rearing program will increase the number of prospective dairy cows that will have an impact on increasing business scale, as Asmara et al. stated that the level of technical efficiency of large-scale business of dairy cattle is higher than that of small-scale with a technical efficiency distribution of $0.80-1.00$ [21]. Small-scale dairy farming is relatively less profitable than medium and large-scale dairy farming [22].

Scenario 4, namely the scenario combination of increasing milk productivity, calf rearing, and imports of broodstocks, is very effective in reducing the milk deficit become 
$18.41 \%$ in 2025 . As for the import of the broodstock scheme, the government needs to import 500,000 broodstocks in the stages of 5 years and ship them in five stages. Each shipment has a 1-year interval. Therefore, if the government simultaneously applies these scenarios, by 2025 , the national milk production can reach $81.59 \%$. In this condition, the quantity of milk imports is quite low, and this will be an achievement throughout the history of dairy in Indonesia. According to Nor et al. in a herd of 100 cows, the optimal number of female calves raised as a substitute for heifers is $73 \%$ of the total female calves. This optimal percentage will minimize the average net cost of replacement [23]. However, this scenario requires very large budget support and the readiness of all relevant stakeholders when implemented. It is recommended to develop dairy cattle populations and expand pastures outside of Java to support this situation. Strengthening the downstream system, starting from cooperatives, IPS, and distribution channels with the support of government policies and financial institutions is necessary to be done. It will support the successful implementation of the acceleration model for fresh milk availability in Indonesia. Research by Soeun and Jiyoung found that partnerships between coffee producers and alternative trade organizations benefit fair trade partners [24]. Bosire et al. pointed out that to increase meat and milk production can be obtained through intensive programs, which depend on the successful establishment and implementation of supporting policies, institutional arrangements, availability of markets and information, and other basic requirements [25]. .

\section{Conclusions and policy implication}

The implementation of a 5\% tariff policy on milk imports has an impact on increasing producer surplus, reducing consumer surplus, and reducing public welfare. The $5 \%$ import tax generates government revenue. The import tariff policy will increase prices in the domestic market and prices at the producer level so that domestic producers will increase their production. A decline in consumer demand and an increase in production (supply) will eventually decrease milk imports, which will encourage an increase in domestic milk production.

The policy recommendations are based on the simulation results of the model. Scenario 3 is a combination of policy scenarios for improving milk productivity and calf rearing policies, simulating milk production in 2025 to $49.75 \%$. Scenario 4 is a combination of Scenario 3 and the parent import policy, which is the best possible scenario. In 2025, the proportion of national fresh milk production (SSDN) will increase by $81.59 \%$.

The implications of import tariff policies, which is supported by programs to optimize the development of national milk from the producer side, namely, the need for land for dairy cattle farming (expansion to outside Java), the need for forage land, additional labor, and encouraging regional/national economic growth. The increase in fresh milk production needs to be followed by an increase in fresh milk consumption.

\section{References}

1. PUSDATIN. Outlook, (2019).

2. BPS. Statistik (2021).

3. Kemenkeu. Permenkeu (2017)

4. Kemenko Perekonomian. Blueprint, (2013)

5. Kemenkeu. Kepmenkeu, (1998) 
6. E. Rasmikayati, E. A. Elfadina, R. A. B. Kusumo, B. R. Saefudin, Supriyadi. J. Manajemen dan Agribisnis, 17, 1, (2020).

7. M. Z. Abidin. Sosio Informa 1(3), 213, (2015)

8. E. Nurhiasati, M. Rifai, Asnah, Wahyunindyawati. Buana Sains, 10(1), 47, (2010).

9. W. Widyawati, Syafrial, M.M. Mustadjab. Habitat. 25(2), 125, (2014).

10. M. Amiti, S. J. Redding, D. E. Weinstein. J. of Ec. Perspectives. 33(4), 187, (2019).

11. J.F. Sinuraya, B.M. Sinaga, R. Oktaviani, B. Hutabarat. J. Agro Ek. 35(1) 11 (2017).

12. A. I. Putri, B. M. Sinaga, N. K. Hidayat, Hastuti. J. Ek. Pertanian, Sumberdaya, dan Lingkungan. 2, 68 (2014).

13. A. Fitriana, B. M. Sinaga, Hastuti. J. Ek. Pertanian, Sumberdaya, dan Lingkungan. 2, 38, (2019).

14. E, Siswanto, B. M. Sinaga, Harianto. J. Ilmu Pertanian Ind. 23(2), 93, (2018).

15. Kementan. Permentan, (2017).

16. Kementan. Permentan (2018).

17. Septiani W, Djatna T. 2015. Agritech. 35(1), 88, (2015).

18. Yudonegoro RJ, Nurwantoro, Hatjanti DW. Animal Agr. J. 3(2), 323, (2014).

19. Lie H, Rich KM, Hoek RVD, Dizyee K. 2018. Agr. Systems. 164, 193, (2018).

20. Rahayu S, Firmansyah C, Kuswaryan S. Sosiohumaniora. 17(2), 126, (2015).

21. Asmara A, Purnamadewi YL, Lubis D. 2016. J. Manajemen \& Agribisnis. 13(1), 14, (2016).

22. Mandaka S, Hutagaol MP. 2005.. J. Agro Ekonomi. 23(2), 191, (2005).

23. N. Mohd Nor, W. Steeneveld, M. C. M. Mourits, H. Hogeveen. J. Dairy Sci. 98, 1, (2015).

24. K. Soeun, K. A. Jiyoung. J. of Distribution Sci. 14(12), 43, (2016).

25. C. Bosire, M. S. Krol, M. Mekonnen, J.O. Ogutu, J. de Leeuw, M. Lannerstad, A. Y. Hoekstra. J. Agr. Sys., 145, (2016). 